удк:339.544

DOI https://doi.org/10.32851/2708-0366/2021.6.6

Капліна A.I.

кандидат економічних наук, доцент кафеери менеджменту та інформаційних технологій, Херсонський державний аграрно-економічний університет ORCID: https://orcid.org/0000-0001-6714-797X

\author{
Kaplina Anastasiia
}

Kherson State Agrarian and Economic University

\title{
ПСИХОЛОГІЧНІ ОСОБЛИВОСТІ ТА ЇХ УРАХУВАННЯ У КРОС-КУЛЬТУРНОМУ МЕНЕДЖМЕНТІ
}

\section{PSYCHOLOGICAL CHARACTERISTICS AND THEIR CONSIDERATION IN CROSS-CULTURAL MANAGEMENT}

Сьогодні все більш суттєвим стає систематичне налагодження відносин між Україною та Китаєм. У зв'язку із ичм велике значення мають етнокультурні відмінності, які знаходяться у корені ділових взаємовідносин між різними компаніями. Сьогодні відбувається у великій кількості вливання китайських інвестииій в украӥнську економіку, у результаті тісної співпрачі необхідно намагатися досягати взаєморозуміння та взаємопроникнення та доповнення економік між краӥнами. Найбільш важливим завданням в умовах, які склалися, є вивчення та застосування конфуиіанської етики, урахування ї̈ впливу на культуру та ділові традииї переговорів. Унаслідок глобалізаиії світової економіки, в якій залучено представники різних культур, необхідно намагатися збільшувати коло бізнес-контактів на світовому ринку, розиирювати інвестичії за кордоном, підвищувати загальну культури під час роботи у крос-культурному середовищі, будувати адаптивну систему менеджменту на основі вивчення досвіду найкращих світових компаній.

Ключові слова: крос-культурний менеджмент, управлінські рішення, культура, контролінг, інтернаціональний менеджер, переговори.

В последнее время систематическое установление отношений между Украиной и Китаем становится все более значимым. В связи с этим большое значение имеют этнокультурные различия, которые являются основой деловых отнотений между различными компаниями. Сегодня идет большой объем вливания китайских инвестиций в украинскую экономику, в результате тесного сотрудничества необходимо постараться добиться взаимопонимания и взаимной проницаемости и дополнить экономику между странами. Наиболее важной задачей в нынешних условиях является изучение и применение конфучианской этики, учитывая ее влияние на культуру и бизнес-традииии переговоров. В результате глобализации мировой экономики, в которой участвуют представители разных культур, необходимо постараться расширить спектр деловых контактов на мировом рынке, расширить инвестищи за рубежом, повысить общую культуру при работе в межкультурной среде, выстрочть адаптивную систему управления, основанную на изучении опыта лучших мировых компаний.

Ключевые слова: межскультурное управление, управленческие решения, культура, контроль, международный менеджер, переговоры.

Recently, the systematic establishment relations between Ukraine and China has become increasingly significant. In this regard, ethnocultural differences, which are at the root business relations between different companies, are great importance. Today, there is a large amount of infusion Chinese investments into the Ukrainian economy, as a result of close cooperation it is necessary to try to achieve mutual understanding and mutual permeability and complement economies between the countries. The effectiveness these relations determines the need to take into account the phenomenon of cross-cultural management in the construction of business relations. The most important task in the current conditions is the study and application of Confucian ethics, taking into account its impact on the culture and business traditions of negotiations 
will allow to intensify the decision-making process in international business. As a result of the globalization of the world economy, in which representatives of different cultures are involved, it is necessary to try to increase the range of business contacts in the world market, expand investments abroad, increase the overall culture when working in a cross-cultural environment, build an adaptive management system based on the study of the experience of the world's best companies. For a clear organization work, it is necessary to keep records all the nuances that can manifest themselves in joint production when making management decisions with representatives different cultures. Cross-cultural skills include: understanding the nature of culture and the fact that culture affects human behavior in his workplace; understanding the differences between cultures; understanding how cultural factors affect the organization of structures, systems and priorities; the ability to introduce elements of one culture to another; understanding how deeply elements of one culture can be introduced into another, and vice versa. Contraindications in the work of the international manager is ethnocentrism, that is, the desire to "fit" representatives of one culture into their own framework and expect them to meet these norms of behavior.

Key words: cross-cultural management, management decisions, culture, control, international manager, negotiations.

Постановка проблеми. Ми є свідками зародження економічних зв'язків між Україною та Китаєм, що проявляється у збільшенні кількості обсягу китайських інвестицій та кількості підприємств із китайським капіталом в Україні, а також у доповненні та взаємопроникненні української та китайської економік. Соціокультурні особливості Китаю впливають не на економічне та політичне життя не лише цієї країни, а й інших країн, оскільки китайські підприємства та китайський капітал більшою мірою приймають участь у процесах глобалізації.

Аналіз останніх досліджень і публікацій. Поштовхом до розвитку крос-культурного менеджменту та аналізу взаємовідносин між китайської та української стороною стали реалізація китайського плану та проникнення китайської економіки на іноземні ринки [1]. Однак по-справжньому бурхливий інтерес до проблематики крос-культурного менеджменту, етнопсихологічних особливостей виник у Європі наприкінці 80-х початку 90-х років, коли опублікувалися основні дослідження голландців Г. Гофстеде і Ф. Тромпенаарса [2] та американця Найджела Холдена [3], які сьогодні стали класиками та авторитетами крос-культурного менеджменту. Нині праці деяких російських та українських учених, зокрема Л. Борисової [4], С. Мясоєдова [5], Ю. Петрущенко [6], О. Романухи [7], присвячені аналізу національних бізнес-культур за класифікаційними параметрами вищезгаданих моделей [8].

Формулювання цілей статті. Сучасний український менеджер повинен мати у своєму арсеналі платформу знань науково-практичного інструментарію для діагностики та управління міжкультурними відмінностями в компанії. Наукова література, статті, публікації, присвячені крос-культурному менеджменту, представлені англійською, українською, китайською мовами. Проте у сучасних книжкових магазинах відсутня література, присвячена особливостям проведення переговорів із представниками різних культур або організації управління персоналом компанії в умовах іншої субкультури, засобам адаптації співробітників, направлених на роботу за кордон [8; 9].

У статті намагаємося проаналізувати основні етнопсихологічні особливості різних багатонаціональних культур (зокрема, китайської ділової культури та української), основні фактори, цілі та завдання феномену крос-культурного менеджменту, методи, які можуть бути використані під час написання підручників або в роботі менеджерів із персоналу.

Виклад основного матеріалу дослідження. Низка чинників визначає необхідність урахування феномену крос-культурного менеджменту під час побудови ділових відносин із китайськими компаніями:

- глобалізація світової економіки, в якій приймають участь представники різних національних культур; 
- збільшення числа бізнес-контактів на світовому ринку у представників бізнесу різних країн у цілому;

- розширення китайських інвестицій за кордоном та збільшення виробництва 3 китайським капіталом та менеджментом у світі зокрема;

- потреба підвищення загальної культури управлінців, як українських, так i китайських, необхідної у роботі у крос-культурному середовищі;

- побудова системи менеджменту, адаптованої до української культури та менталітету;

- підвищення ефективності роботи організації (виробництва) на основі вивчення досвіду лідируючих світових компаній;

- виникнення в деяких випадках «крос-культурного шоку», викликаного нерозумінням особливостей іншої культури, способу життя, менталітету, етнопсихологічних особливостей носіїв культури різних країн, які можуть проявлятися у веденні спільного виробництва та під час прийняття управлінських рішень.

Можна визначити такі цілі та завдання крос-культурного менеджменту як галузі дослідження і його практичного застосування за взаємодії двох культур:

1) уміння провести переговори з представниками іншої культури;

2) здатність швидко залагодити конфлікт у команді, де працюють представники різних культур;

3) здатність побудувати систему мотивації у компаніях, де працюють представники різних культур;

4) здатність визначити необхідні характеристики лідерства.

Етнокультурні відмінності впливають на крос-культурний менеджмент. Культурні особливості визначаються культурним середовищем, а етнопсихологічні особливості - місцем народження, етнічною приналежністю, місцем проживання. Ці відмінності можна продемонструвати на прикладі взаємодії представників західної культурної традиції та китаєцентричної культурної традиції або конфуціанської культурної традиції. Китаєцентричними ми називаємо країни, культура яких більшою мірою визначається конфуціанської етикою (Китай, Корея, В’єтнам, Японія).

Специфіка проведення переговорів із представниками китаєцентричної культури визначена, перш за все, конфуціанською етикою та культурною традицією, яка принципово відмінна від західної, європейської культурної традиції ведення переговорів. Вплив конфуціанської етики на культуру та ділову традицію переговорів величезна. Конфуціанська етика формує ритуал - набір правильних зразків поведінки, у тому числі у ході ведення ділових переговорів. Ритуал та етнопсихологічні особливості формують методи досягнення вищевказаних ключових позицій:

1. Авторитет сторін у конфуціанскій традиції визначається віком та статусом учасника перемовин. Для західної культурної традиції характерно приділяти увагу досвіду, кваліфікації та компетенції. Необхідно приймати участь рівностатусних партнерів під час переговорів різнокультурних груп.

2. Китайська традиція виключає прямий конфлікт та агресію у взаємовідносинах, що пов'язано з «етикою обличчя». У зв'язку із цим «жорсткі перемовини», поняття, характерне для західної культурної традиції, недопустимі. Китайська сторона, як правило, займає пасивну вичікувальну позицію, реагуючи на зовнішні виклики. Конфлікт сторін, згідно з китайською традицією, не може бути вирішений у прямому протистоянні. На відміну від західної культури, де перемога у відкритому конфлікті - досягнення, вирішення конфлікту у китайському розумінні можливе лише у ході досягнення компромісу. У зв'язку із цим величезну роль може відігравати третя сторона або посередник, який залучається до врегулювання. Цей посередник повинен володіти авторитетом для всіх стороні перемовин.

3. Як приймаються рішення - важливий процес, який кожна зі сторін намагається зрозуміти. Якщо для західної культурної традиції характерна раціональність, розраху- 
нок, прогноз та планування, то у китайській діловій традиції превалює ірраціонально-інтуітивні методи прийняття рішень, особливо в умовах невизначеності та ризику. Якщо західна теорія управління побудована на основі допущенні можливості уникнення невизначеності у прийнятті рішення за допомогою прогнозу та планування діяльності, то китайській традиції це не властиво - приймати рішення може тільки одна людина.

4. Необхідно відзначити підвищену скрупульозність до деталей переговорів та змісту договору з боку представників китайської культурної традиції, що пов'язано 3 особливостями мислення від зального до часткового, тоді як представники західної культури схильні до дедукції - формування з деталей загальної картини.

5. Відповідно до загальних уявлень, компроміс - умови угоди, прийняті сторонами у результаті проведення переговорів. I якщо для західної культурної традиції компроміс - це завжди результат досягнутих угод, але не завжди рівноцінний для обох сторін, для китайської культурної традиції компроміс - це взаємовигідні умови угоди, тільки такі у подальшому мають перспективу виконання.

6. Західна культурна традиція велике значення приділяє контракту як письмовій угоді між сторонами, що закріплено у Віденській конвенції про договори від 1980 р. Умови підписаного контракту непорушні та повинні виконуватися під страхом судового переслідування. Однак під час проведення переговорів та укладання угоди 3 китайською стороною необхідно враховувати нікчемність контакту та підвищену увагу до усних домовленостей, у тому числі особистим контактів та гарантій у китайській культурній традиції.

7. Виконання зобов'язань по угоді, виходячи з вищевказаного, залежатиме від того, як сторони сприймають умови підписаного договору та чи знайдено компроміс. Відсутність такого не надає гарантій умов виконання угоди навіть за умови наявності підписаного контракту.

Висновки. Своєчасне урахування вищеперерахованих етнопсихологічних особливостей дає змогу активізувати процес прийняття рішень у міжнародному бізнесі, учасниками яких є представники китайської та української культур. Планомірне використання цих показників дасть змогу значно знизити ризики крос-культурної взаємодії, підвищити ефективність прийняття управлінських рівень. Як будь-який тип організації, китайські підприємства мають свої сильні та слабкі сторони, але давати об'єктивну оцінку їхньої діяльності досить важко. До переваг таких компаній можна віднести порівняно високий рівень сполученості колективу, ефективну співпрацю завдяки стійким особистим зв'язкам, низькі трансакційні витрати, здатність швидко реагувати на зміни, відсутність необхідності у жорсткому контролі персоналу та виробництва. Серед недоліків можна назвати відсутність ініціатив та інновацій у середовищі підлеглих другого рівня та чіткої стратегії у керівництві, брак професіоналізму, постійну загрозу розподілу персоналу на фракції, які суперничають один з одним та обмежені можливості для співпраці.

Таким чином, найбільш значимою особливістю китайської ділової співпраці є загальна аморфність окремих конгломератів компаній та всієї бізнес-павутини ділового співтовариства за наявності твердої патерналістської влади хазяїна у переважно сімейній фірмі. Це заважає визначенню кредитних рейтингів для китайських корпорацій, а також для отримання будь-якої інформації про діяльність окремих китайських підприємців. Переважне значення загальної павутини зв'язків заважає виникненню у китайському бізнесі яскравих корпоративних брендів. Усе це $\epsilon$ особливістю китайського стилю менеджменту, яку необхідно враховувати у процесі розвитку партнерських відносин.

\section{Список використаних джерел:}

1. Black J., Mendenhall M. Cross-culture training effectiveness: a revive and theoretical framework for future research. Academy of Management Review. 1990. № 15. P. 1131-1136. 
2. Evans S. Conflict can be positive. HR Magazine. 1992. № 37(5). P. 49-51.

3. Laurent A. The Cross-cultural Puzzle of International Human Resources Management. Human Resources Management. 1986. № 25(1). P. 91-102.

4. Бунина В. Кросс-культурный менеджмент и межкультурная коммуникация. Москва : ГУУ, 2008.

5. Холден Н. Кросс-культурный менеджмент. Концепция когнитивного менеджмента. Москва : Юнити-Дана, 2005. С. 364.

6. Петрушенко Ю. Крос-культурні аспекти підвищення ефективності міжнародного бізнесу. Вісник Хмельнищького наиіонального університету. 2009. № 5. URL: http://journals.khnu.km.ua/ vestnik/pdf/ekon/2009_5_1/pdf/146-148.pdf.

7. Романуха О. Роль крос-культурних комунікацій у менеджменті організацій. Економіка $i$ суспільство. 2017. Вип. 9. URL: http://www.economyandsociety.in.ua/journal/9_ukr/103.pdf.

8. Капліна А.I. Крос-культурний менеджмент як інструмент організації крос-культурної взаємодії. Агросвіт. 2020. № 21. С. 49-52. DOI: 10.32702/2306-6792.2020.21.49.

9. Капліна А.І., Кириченко Н.В. Крос-культурні аспекти управління персоналом. Ефективна економіка. 2020. № 10. URL: http://www.economy.nayka.com.ua/?op=1\&z=8258 (дата звернення: 03.11.2020). DOI: 10.32702/2307-2105-2020.10.58.

\section{References:}

1. Black J., Mendenhall M. (1990) Cross-culture training effectiveness: a revive and theoretical framework for future research. Academy of Management Review, vol. 15, pp. 1131-1136.

2. Evans S. (1992) Conflict can be positive. HR Magazine, vol. 37 (5), pp. 49-51.

3. Laurent A. (1986) The Cross-cultural Puzzle of International Human Resources Management. Human Resources Management, vol. 25(1), pp.91-102.

4. Bunina V. (2008) Cross-cultural management and intercultural kommunikia. GUU.

5. Holden N. (2005) Cross-Cultural Management. The concept of cognitive management. Moscow: Unity Dana, pp. 364.

6. Petrushenko Yu (2009) Cross-cultural aspects of improving the efficiency of international business. Bulletin of Khmelnitsky National University, vol. 5. Available at: http://journals.khnu.km.ua/ vestnik/pdf/ekon/2009 5 1/pdf/146-148.pdf (accessed 22 September 2020).

7. Romanukha O. (2017) The role of cross-cultural communications in the management of organizations. Economics and society, vol. 9. Available at: http://www.economyandsociety.in.ua/journal/9_ukr/103.pdf (accessed 22 September 2020).

8. Kaplina A. I. (2020) Cross-cultural management as an instrument of organization of cross-cultural interaction. Agrosvit. vol. 21, pp. 49-52.

9. Kaplina A., Kyrychenko N. (2020) Cross-cultural aspects of human resources management. Efektyvna ekonomika, vol. 10. 